\title{
The Impact of Xenophobic Attacks on the Livelihoods of Migrants in Selected Provinces of South Africa
}

\author{
Enoch Rabotata ${ }^{1}$, Jabulani Makhubele ${ }^{1}$, Themba Baloyi ${ }^{2}$, Prudence Mafa ${ }^{1}$, Motshidisi \\ Kwakwa $^{1}$, Tuelo Masilo ${ }^{1}$, Frans Matlakala ${ }^{3,{ }^{*}}$ and Allan Mabasa ${ }^{2}$ \\ ${ }^{1}$ University of Limpopo, Department of Social Work, South Africa \\ ${ }^{2}$ University of Venda, Department of Social Work, South Africa \\ ${ }^{3}$ North West University, Mafikeng Campus, Lifestyle Diseases Research Entity, South Africa
}

\begin{abstract}
Migration and xenophobia are realities that cannot be ignored globally. Recently, there has been a plethora of xenophobic attacks as a result of structural and socio-economic conditions in South Africa. This paper aimed to establish the impact of xenophobic attacks on the livelihoods of migrants in selected provinces of South Africa. Researchers opted for a qualitative study using a case study design. Participants were drawn from the population in Limpopo, North-West and Mpumalanga Province. A snowball sampling technique was used to sample seven migrants from Zimbabwe, India, and Ethiopia using semi-structured interviews. Data were analysed thematically. The study revealed that most migrants who reside in the rural areas of South Africa seldom experience xenophobic attacks, and therefore their livelihoods are not always negatively affected. The study concluded that displacement, deportation, and loss of income due to xenophobic attacks are experiences of undocumented migrants in the cities and not in the rural areas. This study also makes recommendations that migration management policies be implemented fully in the rural areas because this is where undocumented migrants find comfort.
\end{abstract}

Keywords: Impact, Xenophobic attacks, Livelihoods, and Migrants.

\section{INTRODUCTION AND BACKGROUND INFORMATION}

Recently in the years 2008 and 2015, South Africa had a plethora of xenophobic attacks as a result of structural and socio-economic conditions. The term xenophobia involves negative social representations and practices that discriminate against immigrants, refugees, and migrants (Rydgren 2004; Roemer and Van der Straeten 2007). Such practices are often seen as correct by natives because of negative and false beliefs attributed towards migrants in South Africa.

Within a decade, xenophobia has emerged as one of the major contributing factors to urban violence in many African countries, and the phenomenon is becoming an urban management challenge that deserves academic inquiry and policy attention (Tevera 2013; Crush and Ramachandran 2009; Hassim et al. 2008). Xenophobia and its various forms of intolerance place migrants in unfavourable living conditions within the host country because sometimes they are banned from accessing basic services that they are entitled to, such as public health, education, shelter, potable water, and sanitation (Taran 2000; Tevela 2013; LefkoEverett 2007). Faturiyele et al. (2018) also found that access to healthcare facilities by undocumented

\footnotetext{
*Address correspondence to this author at the North West University, Mafikeng Campus, Lifestyle Diseases Research Entity, South Africa; Tel: 018299 2872; Fax: 018392 5775; E-mail: fransmatlakala@gmail.com,

koketso.matlakala@nwu.ac.za
}

migrants is problematic in South Africa and threatens their livelihoods.

Xenophobic violence is not new to post-apartheid South Africa. However, the violent attacks against foreign nationals that shocked the country in May and June 2008 were unprecedented in their ferocity, intensity, and rapid geographic spread. Because of these attacks, a vast number of primarily African nonnationals were violently displaced from their communities of 'urban integration' in South African townships. Large numbers of asylum seekers and refugees became internally displaced persons (IDPs), which is an anomaly in terms of the international frameworks on displacement and refuge (Tirivangasi 2017).

Furthermore, in the wake of the attacks, which subsided only after the South African army intervened, those foreign nationals who were not 'voluntarily' repatriated or deported (many of them asylum seekers or refugees) were sheltered in makeshift camps outside police stations until temporary displacement camps were set up to accommodate approximately 20,000 displaced persons in Gauteng and Western Cape Provinces (Lombard 2015). It appears that most of the displaced persons chose to resettle in alternative urban neighbourhoods, or to return to the communities that mobilised against them. But there has been very little action taken to mitigate the possibility of a repeat of the attacks, and no visible government tracking or profiling of these IDPs. 
As stated above, South Africa, mostly around the years 2008 and 2019, faced several waves of xenophobic attacks against refugees and other migrants. Such attacks and violence have been mostly on foreign nationals renting small shops (spaza shops) in rural areas and townships because these shops are mostly run by people from Ethiopia, Somalia, Bangladesh, and Pakistan (Zanker and Moyo 2020). Xenophobic attacks have always had an astounding impact on the lives of migrants. Crush and Ramachandran (2010) found that xenophobic attacks leave migrants in devastating situations such as the loss of lives, rape, and the majority of them are displaced. This has a severe impact on the lives of Africans because the scars and mistrust created by these attacks leave displaced families distorted for the most part of their lives (Tirivangasi and Nyahunda 2020). Displaced family members find it difficult to find each other for the better part of their lives.

Furthermore, Crush et al. (2018) averred that xenophobia in South Africa translates into a broad spectrum of behaviours, including discriminatory, stereotyping, and dehumanising remarks. They further pointed out discriminatory policies and practices by government and private officials such as the exclusion of migrants from public services to which they are entitled to. These authors highlight that selective enforcement of by-laws by local authorities, assault and harassment by state agents, particularly the police and immigration officials, as well as public threats and violence, are some of the discriminatory practices experienced by migrants which can safely be said to be xenophobic attacks. Some migrants lose their lives in the process.

There are provinces in South Africa (Western Cape, Kwazulu-Natal, and Gauteng) that have experienced tragic xenophobic violence which, in most areas, were targeted at small businesses owned by migrants such as spaza shops (Crush et al. 2018). These researchers further noted that in the years 2005 to 2006 , incidents occurred in six distinct locations within the three provinces. The attacks have resulted in natives using the protests as an opportunity to address their hunger issues since they have a chance to steal from migrant shop owners.

Generally, the Western Cape and Gauteng have experienced the highest levels of this form of xenophobic violence. Each episode of collective violence targeting small businesses includes some combination of the following: written or verbal threats and insults; public intimidation through protests or marches; forced shop closures; direct physical assaults of migrant store owners or their employees; looting of store contents; damage to the physical structure of shops, especially through arson; damage or destruction of other business properties belonging to migrants, including homes and cars; temporary or permanent forced displacement of migrant entrepreneurs and their families from an area; and extortion for protection by local leaders, police, and residents.

In many countries, including European and African countries, undocumented migrants commonly have problems about access to health and social welfare services. Foreign countries create systems that refuse to provide such services by increasing fees that migrants may not be able to afford or through the projection of discriminatory behaviour (Vignier et al. 2018). Undocumented migrants in Botswana and South Africa are perceived by the states and the public as a problem and therefore have to be removed. Arresting, detaining, and deporting undocumented immigrants are some of the major ways in which these countries deal with the 'problem'. According to Gordon (2010), detention and deportation are seen as preventive measures that allow individuals to be taken into custody just because their mere presence is seen as a danger to the security and integrity of the state. In both countries, the 'influx' or 'flood' of undocumented migrants is seen as straining those countries' social services and infrastructure.

\section{AIM AND OBJECTIVES}

The overall goal of this study, therefore, is to explore the impact of xenophobic attacks brought upon migrants by natives on their livelihoods within the selected provinces of South Africa.

From the foregoing, this study attempts to respond to the following objectives: to ascertain how migrants deal with a displacement that came about as a result of xenophobic attacks within the rural areas; to determine experiences relating to being deported due to xenophobic attacks that happen within the rural areas, and to appraise income losses emanating from xenophobic attacks in the rural areas of South Africa.

\section{METHODS}

\subsection{Research Settings}

This qualitative study was conducted in Mahikeng, Tonga, and Musina, which are located in three selected 
provinces of South Africa. The areas were chosen because they are some of the areas within the selected provinces with migrants who are involved in different forms of means for survival. For example, some are involved in agricultural businesses, some own shops, and others depend on peace jobs related to skills they learned in schools in their respective countries.

\subsection{Population and Sampling}

Study participants consisted of migrants from countries such as Zimbabwe, Ethiopia, and India. Participation was based on those who were identified by the first interviewee, was available at the time of the interview, and easy to reach as some of them closed their shops very late and could not participate in the study. The sample was selected through the random sampling technique from the above-mentioned countries. Participants were recruited from the three selected provinces (Limpopo, North-West and Mpumalanga) through referral by the first migrant from each province, who then identified other participants (purposive and snowball sampling). Migrants who chose to participate in the study were briefed on the nature and purpose of the interview and had an opportunity to discuss verbal consent. An interview guide was followed to generate data.

\subsection{Data Analysis}

Data was analysed through thematic content analysis. Raw data from interview transcripts, field notes, and recordings were coded, and themes were developed so that meanings could be interpreted and conclusions made (O'Leary 2017). These included knowledge and perceptions of participants on the subject matter. The researchers followed O'Leary's five steps of analysing data

\section{RESULTS AND DISCUSSIONS}

The study generated three main themes, namely: displacement of migrants due to xenophobic attacks; migrants' experiences of deportation caused by xenophobia; and the loss of income by migrants due to xenophobic attacks.

\subsection{Displacement}

Xenophobic attacks in any country generally always leave the attacked migrants devastated and dispersed throughout the country. The migrants would often find themselves scattered around the whole nation and struggling to find each other. The majority of participants highlighted that they have never experienced xenophobic attacks in areas where they find themselves currently. They, however, indicated that the only time in which they experienced anger from natives in the rural areas was when one of the migrants found his native girlfriend having committed suicide in his room, and when one of them had a fight while gambling with the natives. This triggered xenophobic attacks. One of the participants indicated that:

"I find it very rare that our brothers would report being experiencing xenophobia because the people in these rural areas are good to us and they even support our businesses. They are good people and we seldom have quarrels with them as they also gave us places to stay and spazashops to run so that we can have income".

The other respondent said:

"Yes in the cities we do hear of xenophobia and some of our brothers were killed, but in these areas, we are in we never experience xenophobia. Back in the years when there were attacks in Pretoria some of our brothers ran away and came to this side of the country because it was bad on the other side. Those who could not locate us we're able to find help from other brothers who were also in Gauteng province but in areas where there were no attacks. It was easy because we support each other even when we do not necessarily know each other, but for the fact that we are from the same country it is easy for us to find one another".

Basardien et al. (2014) found that small businesses such as spaza shops run by foreign nationals are more effective than those run by natives simply because foreign nationals are said to have more business skills than South African citizens. Therefore, instead of South Africans establishing and running businesses on their own, they erect buildings in their backyards that are leased out to foreign nationals to be utilised as spaza shops. These authors also indicate that natives in the rural areas benefit more from these businesses because the rental charged helps sustain their lives. Thus they cannot engage in xenophobic attacks against their tenants. 
This paper argues that violent protests against foreign nationals are limited because there is a mutual benefit between the citizens and foreign-born nationals in the rural areas. Also, the principles of Ubuntu are mostly adhered to in black rural communities such as those in which this study was conducted. Black people are generally known for their respect, sense of unity, mutual aid, and humility. The findings of this paper also show that because of little to no occurrence of xenophobic attacks in the rural areas, migrants do not find themselves displaced.

\subsection{Deportation}

The majority of participants reported having experienced deportation as a result of xenophobic attacks. This is mainly because, at the time of the attacks, they were found without proper documentation required to stay in the country. This finding resonates with a study conducted by Buenavista (2018), which found that undocumented migrants do get deported for document-related reasons. Participants, however, reported that they always find a way to come back into the country still without documents. Furthermore, participants indicated that:

"Even though xenophobic attacks leave us with the frustrations of deportation, it is very easy to re-gain entry into South Africa as the borders are not very strict if one has money".

According to the majority of respondents, as reentry into the country is achieved, rural areas become their targeted place of arrival. They settle there because there are fewer dangerous xenophobic attacks as opposed to the cities. People in the rural areas are more receptive to migrants and even give them native names. One participant reported that:

"When I arrived back from my home country in 2016 after I was deported from South Africa in 2015, I decided not to go back to the city but opted to settle in a rural community where I established my business. I was warmly accepted by the members of the community and I felt very safe. They are so receptive that they even gave me a native name, hence I go by the Tsonga name".

In the rural areas, attitudinal xenophobia that they receive from individual members of the communities does not escalate to a mob attack that would even result in police forces getting involved to a point of deportation. Participants also made mention of the fact that they are aware of the impact that deportation has on their livelihoods because when such incidents happen, their ecosystems are disturbed; and their survival strategies are also disturbed because at times when the breadwinner is deported, the wife and children would remain behind suffering.

\subsection{Loss of Income}

It is a known fact that when xenophobic attacks happen in any given location, businesses and other means of survival for migrants are always affected negatively. The migrants always suffer income losses, especially those with small businesses such as spaza shops. Migrants in these rural areas reported that they never suffered from xenophobic attacks and therefore could not report the first-hand experience. It is, however, an indisputable fact that the migrants get to know of the xenophobic attack and looting of shops of their fellow migrant from the media and word of mouth from people with first-hand experience. During the interview, one of the respondents reported that:

"All the time when I hear of community
members mobilising to fight against the
foreign nationals I always make sure that I
close my store because these people will
always loot our small shops and make us
lose money".

Similar sentiments were expressed by another respondent who highlighted that:

"Xenophobic riots that we somehow get to
experience are in most cases started by
people whose main intention is to loot in
our shops, that's why all the time we will
close the shops to avoid loss of stock
whenever people prove to be restless".

A study by Mamabolo (2015) indicated that natives will always find a reason to attack migrants because some of the causes of these xenophobic attacks include hunger. Therefore they attack foreigners' shops to create an opportunity to loot them to satisfy their stomach politics. This looting of spaza shops leaves the migrants economically challenged due to the losses incurred. This suggests that poverty and unemployment also lead to the looting of foreigners' shops during xenophobic protests in the country. 


\section{CONCLUSION}

This study aimed to zoom into the lives of migrants in as far as the impact of xenophobic attacks on the quality of their lives. Despite rigorous engagement with participants regarding their experiences with xenophobic attacks in rural areas, the study revealed that migrants in rural areas feel that they seldom experience xenophobic attacks compared to their urban counterparts. The study has, however, revealed that those who were deported from the country during xenophobic attacks in the cities chose to dwell in the rural areas when they finally regain entry into the country. The study has also highlighted that due to non-hard xenophobia in rural areas, issues such as displacement, deportation, and loss of income are rarely observed because such attacks are less harsh and do not extend over a long period.

The study findings contribute to the broader knowledge base of the social work and allied professions in respect of migrant populations. Furthermore, the findings of this article foster interprofessional collaborations amongst social workers, educators, health care professionals, and other professionals involved with migrants to understand the impact of xenophobic attacks on their (migrants') livelihoods in selected provinces of South Africa. To this end, this study recommends that future studies should evaluate the effective implementation of migrant management policies in rural areas because, in terms of findings, this is where undocumented migrants find comfort within the country.

\section{ACKNOWLEDGEMENT}

The authors thank participants who took part in this study. We also thank the National Institute for the Humanities and Social Sciences (NIHSS) for providing funding for this study.

\section{REFERENCES}

Basardien, F., Parker, H., Bayat, M. S., Friedrich, C., \& Appoles, S. 2014. "Entrepreneurial orientation of spaza shop entrepreneurs evidence from a study of South African and Somali owned spaza shop entrepreneurs in Khayelitsha." Singaporean Journal of Business, Economics and Management Studies, 51(1447): 1-17. https://doi.org/10.12816/0006774

Crush, J., \& Ramachandran, S. 2009. Xenophobia, international migration and human development. New York: United Nations Development Programme. https://doi.org/10.1080/19452821003677327
Crush, J., \& Ramachandran, S. 2010. "Xenophobia, international migration and development." Journal of Human Development and Capabilities, 11(2): 209-228.

Crush, J., Tawodzera, G., Chikanda, A., Ramachandran, S., \& Tevera, D. S. (2018).Migrants in Countries in Crisis: South Africa Case Study: The Double Crisis-Mass Migration From Zimbabwe And Xenophobic Violence in South Africa. Vienna: International Centre for Migration Policy Development.

Faturiyele, I., Karletsos, D., Ntene-Sealiete, K., Musekiwa, A., Khabo, M., Mariti, M., \& Pisa, P. T. 2018. "Access to HIV care and treatment for migrants between Lesotho and South Africa: a mixed methods study." BMC public health, 18(1): 668 . https://doi.org/10.1186/s12889-018-5594-3

Fauvelle-Aymar, C. \& Segatti, A. 2011. 'People, Space and Politics: An Exploration of Factors Explaining the 2008 Anti-foreigner Violence in South Africa.' In L. Landau (ed.). Exorcising the Demons Within: Xenophobia, Violence and Statecraft in Contemporary South Africa. Johannesburg: Wits University Press, 56-88

Gordon, S.L., 2010. "Migrants in a state of exception." Transcience Journal, 1(1): 3-21.

Hassim, S., Kupe T. \& Worby, E. 2008. Go home or die here: violence, xenophobia and the reinvention of difference in South Africa. NYU Press. https://doi.org/10.18772/22008114877

Lachica Buenavista, T. 2018. "Model (undocumented) minorities and "illegal" immigrants: Centering Asian Americans and US carcerality in undocumented student discourse." Race Ethnicity and Education, 21(1), 78-91. https://doi.org/10.1080/13613324.2016.1248823

Lefko-Everett, K. 2007. Voices from the margins: migrant women's experiences in southern Africa. SAMP Migration Policy Series No. 46. SAMP: Cape Town.

Lombard, F. 2015. Policies and programmes to reduce xenophobic violence against black African foreign nationals in South Africa: a case study of the City of Cape Town's metro police and business areas management: 2008-2013 (Masters Dissertation). University of the Western Cape.

Mamabolo, M. A. 2015. "Drivers of community xenophobic attacks in South Africa: poverty and unemployment." TD: The Journal for Transdisciplinary Research in Southern Africa, 11(4): 143150. https://doi.org/10.4102/td.v11i4.49

O'leary, Z. 2017. The essential guide to doing your research project. Sage.

Roemer, J. E., Elizabeth, S., Lee, W., van der Straeten, K., \& Yi, U. J. 2007. Racism, xenophobia, and distribution: Multi-issue politics in advanced democracies. Harvard University Press.

Rydgren, J. 2004. "The logic of xenophobia." Rationality and society, 16(2), 123-148. https://doi.org/10.1177/1043463104043712

Taran, Y. A., Bernard, A., Gavilanes, J. C., \& Africano, F. 2000 "Native gold in mineral precipitates from high-temperature volcanic gases of Colima volcano, Mexico." Applied Geochemistry, 15(3): 337-346. https://doi.org/10.1016/S0883-2927(99)00052-9

Tevera, D. 2013. "African migrants, xenophobia and urban violence in post-apartheid South Africa." Alternation 7: 9-26

Tirivangasi, H. M. 2017. "The efficiency of strategies for the prevention of xenophobia in post-apartheid South Africa." Masters dissertation, Department of Sociology, University of Limpopo.

Tirivangasi, H. M., \& Nyahunda, L. 2020. "Revisiting the Strategies for the Prevention of Xenophobia in Post-Apartheid South Africa." African Renaissance, 17(3): 203-228. https://doi.org/10.31920/2516-5305/2020/17n3a11 
Vignier, N., Dray Spira, R., Pannetier, J., Ravalihasy, A., Gosselin, A., Lert, F., \& Chauvin, P. 2018. "Refusal to provide healthcare to sub-Saharan migrants in France: a comparison according to their HIV and HBV status." European Journal of Public Health, 28(5): 904-910.

https://doi.org/10.1093/eurpub/cky118

Received on 11-11-2020

Accepted on 22-01-2021

Published on 01-02-2021

DOI: https://doi.org/10.6000/1929-4409.2021.10.31

(C) 2021 Rabotata et al.; Licensee Lifescience Global.

This is an open access article licensed under the terms of the Creative Commons Attribution Non-Commercial License (http://creativecommons.org/licenses/by-nc/3.0/) which permits unrestricted, non-commercial use, distribution and reproduction in any medium, provided the work is properly cited.
Zanker, F. L., \& Moyo, K. 2020. "The Corona Virus and Migration Governance in South Africa: Business As Usual?" Africa https://doi.org/10.1177/0002039720925826 Spectrum, 55(1): 100-112. 